\title{
PENERAPAN MODEL PEMBELAJARAN KOOPERATIF TIPE SCRAMBLE UNTUK MENINGKATKAN MOTIVASI DAN HASIL BELAJAR FISIKA SISWA
}

\author{
Baiq azmi sukroyanti \\ program studi pendidikan fisika FSTT UNDIKMA \\ Email : bqazmi@ikipmataram.ac.id
}

\begin{abstract}
ABSTRAK : Penelitian ini bertujuan untuk meningkatkan motivasi dan hasil belajar fisika siswa dengan menerapkan pembelajaran kooperatif tipe scramble pada siswa kelas VIII SMPN 2 Sembalun tahun 2017/2018. Penilitian ini tindakan kelas yang dilakukan dalam dua siklus yang terdiri dari tahap perencanaan, pelaksanaan, observasi, evaluasi, dan refleksi. Masing-Masing siklus terdiri dari dua kali pertemuan. Instrumen yang digunakan motivasi siswa yang diperoleh melalui lembar angket motivasi belajar siswa. Test hasil belajar yang diberikan penelitian menunjukkan bahwa motivasi belajar siswa pada siklus I yaitu sebesar 63,68\% (berkategori rendah), sedangkan pada siklus II terjadi peningkatan sebesar 78,91\% (berarti berkategori cukup). Peningkatan motivasi pada siklus I dan II siswa sebesar 15,23\%. Ketuntasan belajar siswa secara klasikal pada siklus I dan II masingmasing sebesar 48,28\% dan sebesar 86,97\%. Mengalami peningkatan secara klasikal, Disimpulkan bahwa penerapan model pembelajaran kooperatif tipe scramble dapat meningkatkan motivasi dan hasil belajar fisika siswa
\end{abstract}

Kata Kunci: Model Kooperatif Tipe Scramble, Motivasi dan Hasil Belajar

\begin{abstract}
This research aims to improve student, motivation and learning achievement cooperative learning type of scramble at the second year student of SMPN 2 Sembalun in academic year 2017/2018.This research was classroom action research (CAR) with quantitative and qualitative approach. This research was consisting of two cycles and each cycle consists of four meetings those are planning, acting observing and reflecting. The data was obtained from questionnaire and test. The mean score of student, motivation is 63,68\% with low categories in the first cycle and $78,91 \%$ with enough categories in that by the second cycle and there was the improvement $15,23 \%$.while, the mean score of students, learning achievement shows that the first cycle is $48,28 \%$ and 86,97\% in the second cycle .thus, this research can be concluded that by applying cooperative learning type of scramble can improve students, motivation and learning achievement of physics.
\end{abstract}

\section{PENDAHULUAN DAN KAJIAN LITERATUR}

Dalam Undang-Undang No. 20 tahun 2003 menyatakan bahwa pendidikan merupakan usaha sadar dan terencana untuk mewujudkan suasana belajar dan proses pembelajaran agar siswa secara aktif mengembangkan potensi dirinya untuk memiliki kekuatan spiritual, kenyamanan, pengendalian diri, kepribadian, kecerdasan ahlak mulia serta keterampilan yang diperlukan masyarakat, bangsa dan negara, karena pendidikan adalah salah satu faktor pembangunan nasional yang merupakan bagian yang tidak terpisahkan dengan strategi pembangunan nasional [1]

Di era globalisasi sekarang ini ilmu pengetahuan dan teknologi mengalami perkembangan yang sangat pesat. Perkembangan ini terus menerus meningkat dan sangat besar pengaruhnya dalam kehidupan masyarakat, baik secara langsung maupun tidak langsung. Untuk itu di perlukan manusia-manusia terdidik yang mampu menguasai dan beradaptasi dengan perkembangan ilmu pengetahuan dan teknologi tersebut. Indonesia sebagai salah satu negara yang berkembang telah melakukan berbagai usaha agar dapat beradaptasi dengan ilmu pengetahuan dan teknologi, Dalam proses pembelajaran di kelas guru sering menghadapi siswa yang kurang mampu memahami konsep materi pelajaran sehingga siswa memperoleh hasil belajar yang rendah. Salah satu upaya yang dilakukan oleh guru adalah dengan menerapkan metode pembelajaran yang lebih efektif serta membuat seluruh siswa berpatisipasi aktif.Metode pembelajaran yang digunakan harus sesuai dengan materi yang akan diajarkan.

Berdasarkan hasil observasi pada tanggal 28 Oktober 2017 bahwa pembelajaran IPA Fisika kelas VIII SMPN 2 Sembalun Tahun Pelajaran 2017/2018, menunjukan bahwa Mata pelajaran Fisika pada umumnya dikenal sebagai mata pelajaran yang "Ditakuti" dan tidak disukai oleh siswa. 
kecenderungan ini berawal dari pengalaman belajar mereka yang sebelumnya yang kesanya bahwa pelajaran fisika adalah pelajaran yang berat dan serius yang tidak jauh dari persoalan konsep, pemahan konsep, penyelesaian soal yang rumit melalui pendekatan matematis sampai kegiatan praktikum yang menuntut mereka melakukan segala sesuatunya dengan sangat teliti dan cenderung membosankan. Akibatnya tujuan pembelajaran yang diharapkan menjadi sulit dicapai. Hal ini terlihat dari kurangnya minat atau perhatian siswa dalam proses pembelajaran fisika, dimana kebanyakan dari siswa yang ribut dan bermain dalam ruangan saat

Pembelajaran berlangsung khususnya pada siswa kelas VIII yang sangat sulit untuk memahami konsep dan materi fisika, serta kurangnya perhatian mereka untuk tekun dalam proses pembelajaran sehingga saat ujian tiba nilai ujian siswa tidak mencapai KKM. dalam proses memberikan pelajaran selama ini masih menggunakan metode ceramah (Konvensional). Hal tersebut menimbulkan permasalahan yang diindikasikan sebagai faktor penyebab siswa kurang termotivasi selama proses pembelajaran berlangsung dan rendahnya hasil belajar siswa,hal ini terlihat dan perolehan ketuntasan belajar siswa kelas VIII SMPN 2 Sembalun Tahun Pelajaran 2016/2017 seperti yang tertera dalam bentuktabel di bawah ini:

Tabel 1. Presentase Ketuntasan siswa pada mata pelajaran IPA

\begin{tabular}{|c|c|c|c|c|c|}
\hline No & Kelas & Rata & $\begin{array}{c}\text { Tidak } \\
\text { Tuntas }\end{array}$ & Tuntas & $\begin{array}{c}\text { Ketuntasan } \\
\text { Klasikal }\end{array}$ \\
\hline 1 & VIII-A & 67,1 & 16 orang & 14 orang & $46,7 \%$ \\
\hline 2 & VIII-B & 59,1 & 24 orang & 8 orang & $26,7 \%$ \\
\hline
\end{tabular}

Sumber: (Arsip Guru Mata pelajaran IPA Kelas VIII SMPN 2 Sembalun tahun pelajaran 2016/2017).

Dari data di atas menunjukkan bahwa pelajaran IPA Fisika persentase ketuntasan yang rendah, artinya menunjukkan bahwa hasil belajar jauh dari ketuntasan dengan rata-rata persentase ketuntasan klasikal sebesar $37,1 \%$. Suatu kelas dikatakan tuntas belajarnya jika di kelas tersebut telah mencapai ketuntasan klasikal $>85 \%$, Artinya nilai tersebut belum memenuhi ketuntasan klasikal yang ditetapkan

Masalah yang juga sering muncul dalam proses pembelajaran Fisika adalah tingkat pemahaman siswa dalam suatu permasalahan. Hal ini berdampak pada rasa kurang percaya diri siswa, baik dalam bertanya maupun kemauan siswa menyelesaikan soal-soal Dalam hal ini, akan menuntut guru lebih kreatif dalam memilih model belajar yang tepat dalam proses belajar mengajar. Sehingga dari observasi awal yang telah dilakukan tepat digunakan adalah model pembelajaran kooperatif tipe scramble.

Model pembelajaran kooperatif tipe scramble dirancang membantu individu membuka pintu pemecahan masalah, kegiatan tulis menulis, dan memperoleh pandangan Baru dalam berbagai topik. Di kelas, model ini diperkenalkan kepada Para siswa dalam rangkaian bengkel kerja sampai kepada saat dimana mereka dapat menerapkan prosedur secara individu dan kelompok yang sedang bekerja sama. Selain model pembelajaran kooperatif tipe scramble akan mengajak siswa untuk menggunakan proses berpikir dan harus terampil menghubungkan konsep yang ada dalam pembelajaran Fisika itu sendiri.

Berdasarkan Latar belakang di atas maka penulis telah melakukan penelitian tentang "Penerapan Model Pembelajaran Kooperatif Tipe Scramble Untuk Meningkatkan Motivasi dan Hasil Belajar Fisika Siswa Kelas VIII SMP Negeri 2 Sembalun Tahun Pelajaran $2017 / 2018$.

\section{METODE PENELITIAN}

Jenis penelitian yang digunakan dalam penelitian ini adalah Penelitian Tindakan Kelas (PTK) Penelitian tindakan kelas dapat didefinisikan sebagai suatu penelitian tindakan (Classroom action research) yang dilakukan oleh guru yang sekaligus sebagai peneliti. Penelitian ini berlangsung dari bulan November 2017, subyek penelitian ini adalah siswa kelas VIII yang berjumlah 30 siswa.penelitian dilakukan untuk mengetahui peningkatan motivasi dan hasil belajar IPA (Fisika), dengan menggunakan model pemlajaran kooperatif tipe scramble.

\section{HASIL DAN PEMBAHASAN}

a. Hasil Angket Motivasi Belajar Siswa

Dari hasil perhitungan angket motivasi belajar mengalami peningkatan pada siklus 1 sebesar 63,68\% dengan kategori rendah naik menjadi $78,91 \%$ pada siklus II. Proses pengambilan data untuk angket motivasi belajar siswa dilakukan dalam 2 kali pertemuan. Belajar mengajar menggunakan model pembelajaran kooperatif tipe screamble. Diperoleh keterangan hasil bahwa data hasil angket motivasi belajar siswa menggunakan pembelajaran kooperatif tipe scramble. Mengalami peningkatkan pada setiap siklus Dan pada siklus II dengan kategori cukup sehingga dapat disimpulkan bahwa motivasi siswa dengan menerapkan pembelajaran kooperatif tipe scramble mengalami peningkatan pada setiap siklus.

Untuk mengetahui peningkatan kooperatif tipe scramble dapat dilihat pada grafik 1 di bawah ini. 


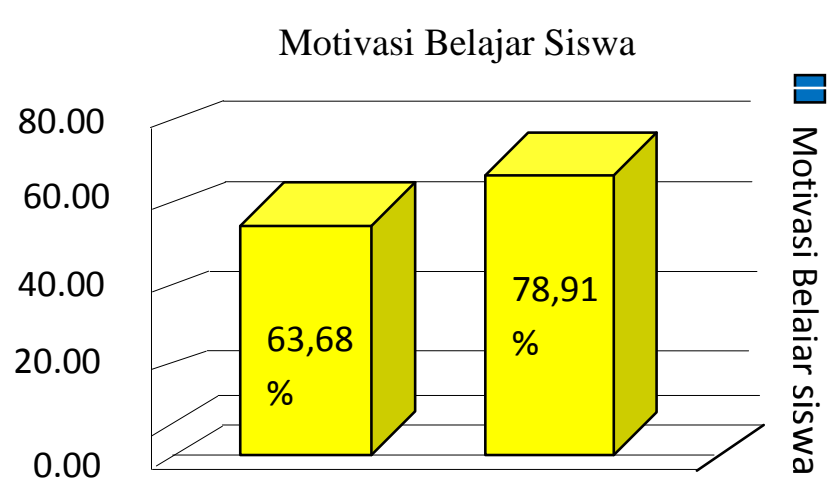

Siklus 1

Siklus II

Grafik 1. Perbandingan peningkatan motivasi

b. Tes hasil Belajar Siswa.

Hasil evaluasi belajar siswa siklus I untuk nilai ratarata siswa sebesar $68,25 \%$ dengan nilai tertinggi yang diperoleh siswa sebesar 83,33 dan nilai terendah yang diperoleh siswa sebesar 54,17, sehingga dari siklus I siswa yang memperoleh nilai $\geq 70$ berjumlah 14 orang dan jumlah siswa yang memperoleh nilai $\leq 70$ berjumlah 15 orang, maka untuk presentase ketuntasan klasikal belajar siswa siklus I sebesar 48,28\%. Hasil tersebut belum dapat dinyatakan tuntas karena belum mencapai standar ketuntasan yaitu $85 \%$, sehinga penelitian harus di lanjutkan ke siklus II. Pada siklus II hasil belajar untuk nilai rata-rata siswa sebesar 78,81 dengan nilai tertinggi yang diperoleh siswa sebesar 60,87 , sehingga dari siklus II siswa yang memperoleh nilai $\geq 70$ berjumlah 25 orang dan jumlah siswa yang memperoleh nilai $\leq 70$ sebanyak 5 orang, sehingga diperoleh presentase ketuntasan klasikal sebesar 86,21 $\%$ (meningkat sebesar 37,93\%). Berdasarkan data di atas, maka hasil belajar siswa di siklus II telah mencapai indikator keberhasilan. Karena indikator keberhasilan telah tercapai maka penelitian dihentikan hingga siklus ke II.

Untuk lebih jelasnya dapat dilihat pada grafik 2 di bawah ini

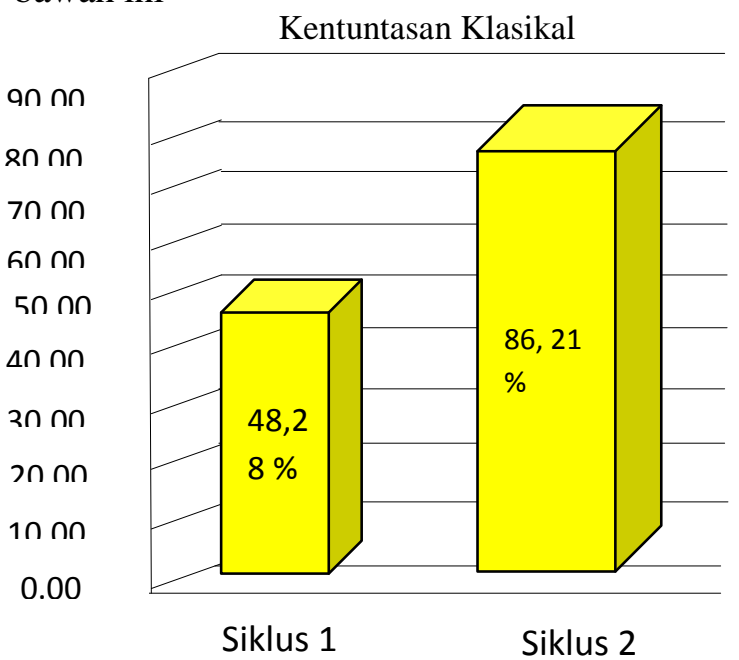

Grafik 2. Perbandingan peningkatan hasil belajar siswa
Tercapainya ketuntasan belajar menggunakan pembelajaran kooperatif tipe scramble karena selama proses pembelajaran berlangsung siswa lebih aktif dalam menggemukakan pendapat dan pertanyaan serta lebih dalam menjawab pernyataan dalam kartu soal, sehingga proses tersebut memancing siswa lain untuk lebih berani mengajukan pendapatnya masing-masing. Hal ini membuat suasana belajar mengajar menjadi lebih hidup.

\section{KESIMPULAN}

Dengan penerapan model pembelajaran kooperatif tipe scramble dapat meningkatkan motivasi dan hasil belajar fisika siswa kelas VIIIA SMPN 2 Sembalun tahun pelajaran 2017/2018. Hal ini dapat dilihat pada perolehan hasil pada siklus I sebesar $63,67 \%$ dan meningkat pada siklus ke II menjadi 78,91\% (meningkat sebesar 15,2\%) Hal ini dapat dilihat dari ketuntasan klasikal pada siklus I sebesar 48, $28 \%$ dan meningkat pada siklus II sebesar 86, $21 \%$ (meningkatkan sebesar 37, 93\%).

Diharapakan kepada guru di SMP Negeri 2 Sembalun, hendaknya dalam pembelajaran menggunakan model pembelajaran kooperatif tipe scramble sebagai salah satu alternatif dalam proses pembelajaran untuk meningkatkan motivasi dan hasil belajar fisika siswa.

\section{DAFTAR PUSTAKA}

[1] Depdiknas. 2003. Undang-Undang RI Nomor 20 Tahun 2003, tentang Sistem Pendidikan Nasional

[2] Abdullah. 2010. Penerapan Model Pembelajaran Kooperatrif Tipe Scramble di Kelas VII SMP Negeri 4 Banjarmasin Tahun Pelajaran 2009/2010. Skripsi Sarjana. Universitas Lambung Mangkurat, Banjarmasin. Tidak dipublikasikan.

[3] Arends, Richard I. (1997).Classroom Instrction and Management. New York: Mc Graw Hill.

[4] Arikunto, Suharsini. 2002. Prosedur Penelitian, Suatu Pendekatan Praktik. Jakarta: PT. Rineka Cipta. 